\title{
FER wt Allele
}

National Cancer Institute

\section{Source}

National Cancer Institute. FER wt Allele. NCI Thesaurus. Code C51074.

Human FER wild-type allele is located within $5 q 21$ and is approximately $440 \mathrm{~kb}$ in length.

This allele, which encodes proto-oncogene tyrosine-protein kinase FER protein, is involved in signal transduction. 